\title{
Doğum tipi değişkeninin anne-bebek etkileşimi ve annenin bebeğini algılaması üzerindeki etkilerinin incelenmesi
}

\section{The investigation of the effects of the birth type variable on the mother-infant interaction and mother's perception of her the infant}

\author{
Demet Çakır, ${ }^{1}$ Özgür Alparslan² \\ 'Sağlık Bakım Hizmetleri, Sabuncuouğlu Şerefeddin Sağlık Hizmetleri Meslek Yüksekokulu, Amasya, Turkey \\ Gaziosmanpaşa Üniversitesi Sağlık Bilimleri Fakültesi Ebelik Bölümü, Tokat, Turkey
}

\section{Özet}

Amaç: Bu araştırma, normal vajinal doğum ile sezaryen doğumun anne bebek etkileşimi ve annenin yenidoğan bebeğini algılaması üzerine etkisinin belirlemek amacı ile kesitsel olarak yapılmıştır.

Gereç ve Yöntem: Araştırmanın evrenini Anadolu'da bir devlet hastanesinde doğum yapan 4457 anne ve yenidoğan, örneklemini ise 01 Ekim-31 Aralık 2007 tarihleri arasında doğum yapan 230 anne ve yenidoğan oluşturmuştur. Araştırmanın verileri, anne-yenidoğan tanıtıcı özelliklerine ilişkin soru formu, Anne-Bebek Etkileşimi Değerlendirme Ölçeği, Yenidoğanı Algılama Ölçeği kullanılarak dört aşamada, gözlem ve yüz yüze görüşme yöntemi ile toplanmıştır. Araştırmadan elde edilen veriler bilgisayarda (SPSS paket program) yüzdelik,ortalama,standart sapma, t testi, ki-kare testi, varyans analizi, ileri Bonferroni testi kullanılarak değerlendirilmiş̧tir.

Bulgular: Sezaryen doğum yapan annelerin ilk temas ve ikinci gün temas anne-bebek etkileşim puanı ortalamalarının 5-7 olduğu (\%72-53.9); vajinal yolla doğum yapan annelere oranla daha fazla ebe/hemşireye ihtiyaç duyduğu belirlenmiştir $(p<0.05)$. Annelerin bebeklerini negatif ve pozitif algılamaları ile doğum şekilleri arasındaki fark istatistiksek olarak anlamlı bulunmamıştır ( $p>0.05$ ). Pozitif algılayan annelerin bebeklerini ilk görme zamanlarına göre istatistiksel olarak anlamlı bir fark bulunmuştur $(p<0.05)$.

Sonuç: Çalışmanın sonucunda özellikle sezaryen doğum yapan annelerin ilk temas ve ikinci gün temas anne-yenidoğan etkileşiminde önemli bir fark ile daha fazla desteğe ihtiyaç duydukları, doğumdan hemen sonra bebeğini görmenin pozitif algıyı artırdığı saptanmıştır.

Anahtar Sözcükler: Anne-bebek etkileşim; ebelik; normal doğum; yeni doğanı algılama; sezaryen doğum.

\begin{abstract}
Introduction: Designed cross-sectionally, this study was conducted to determine the effects of normal vaginal birth and cesarean birth on mother-infant interaction and mother's perception of her infant. Methods: The universe of the study consisted of 4457 mothers who gave birth in a state hospital in Anatolia and their newborns. On the other hand, the sampling involved 230 mothers who gave birth between 1 October and 31 December 2007 and their newborns. The data of the study were collected at four stages through observations and face-to-face interviews using a questionnaire about informative characteristics of mother and newborn, Mother-Infant Interaction Scale, and Neonatal Perception Inventory. The data of the study were evaluated on a computer (SPSS software package) using percent, mean, standard deviation, t-test, Chi-square test, variance analysis, and advanced Bonferroni test.

Results: The mean values of the first and second day contact scores of mother-infant interaction for mothers giving cesarean birth were determined to be 5-7 (\%72-53.9), therefore they were found to need more midwives / nurses compared to mothers giving vaginal birth $(p<0.05)$. The difference between negative and positive maternal perceptions of newborns, and birth types was not found statistically significant ( $p>0.05$ ). A statistically significant difference was found between the first contact time and mothers who perceived their infants positively $(p<0.05)$

Discussion and Conclusion: As a result of the study, it was determined that mothers who had a cesarean birth needed more support with a significant difference in mother-newborn interaction on first contact and second day contact, and that seeing the baby immediately after the birth was found to increase positive perception.
\end{abstract}

Keywords: Mother-baby interaction; midwifery; normal birth; cesarean delivery; perception of newborn.

Corresponding (IIletişim): Özgür Alparslan, Gaziosmanpaşa Üniversitesi Sağlık Bilimleri Fakültesi, Ebelik Bölümü, Tokat, Turkey 
$Y^{2}$ aşamın ilk yılında bebeğe güven, sevgi veren annedir ve özellikle de doğumdan hemen sonra bağlanma duygusunun başarılması, gelecekte çocuğun emosyonel gelişimine temel oluşturmaktadır. ${ }^{[1,2]}$ Yetersiz veya başarısız bağlanma ciddi gelişim ve emosyonel sorunlarına yol açabilmekte, bağlanma güçlüğü olduğunda ise çocuk ihmal edilebilmektedir. ${ }^{[3-6]}$ Anne ile yenidoğanın doğumdan sonra olabildiğince erken birlikte olmaları, 24 saat bir arada kalmaları, bebeğe dokunmaları, emzirmeleri anne-yenidoğan ilişkisinin erken başlamasını ve annenin bebeğini algılamasını kolaylaştırır. Özellikle emzirme, annenin bebeğini olumlu yönde algılamasını sağlar. ${ }^{[1,5,7]}$

Anne bebek etkileşimi ve yenidoğanı algılamada vajinal ve sezaryen doğumun etkilerine bakıldığında ise farklı sonuçlar elde edilmektedir. Normal doğum veya sezaryen doğumun avantaj ve dezavantajları vardır. Sezaryen doğum sonrası oluşan ağrı ve yorgunluk, bebeklerin anestezi nedeniyle uyumaya daha fazla meyilli olmaları ve anneyi dinlendirmek için bebeklerin anne sütü dışında ek gıda ile beslenmeleri emzirmeyi ve anne bebek etkileşimini kötü yönde etkileyebilmektedir. ${ }^{[5,8-11]}$

Vajinal doğumda anne ve bebek arasında duygusal temas daha kısa sürede ve güçlü başlamaktadır. Doğum sonrası anne birkaç saat içinde normal aktivitesine dönebilmekte çok kısa sürede bebeğini emzirmeye başlayabilmektedir. Hastanede kalış süresi son derece kısa olmaktadır. Sezaryen doğum yapan kadınların ise erken dönemde fiziksel ve psikososyal sorunları oldukça yaygındır. Sezaryenle doğum ayrıca anne ile yenidoğan arasındaki etkileşimi geciktirmekte, emzirme ve aile bağlarının sağlanmasında sorunlara neden olabilmektedir. ${ }^{[5,8,10,11]}$

Doğum sonrası ilk günlerde annelerin bebeklerini algılama durumları daha sonraki gün/ay ve yıllarda oluşacak anne-bebek ilişkisinin temelini oluşturur. Annenin bebeğini algılamasında ve anne-bebek ilişkisinin gelişmesinde annenin yaşı, gebeliğin istenme durumu, ailenin sosyo-ekonomik kültürel durumu, aile içi ilişkileri, annenin kendi ailesinden aldığı sevgi ve bebeğin sağlık durumu gibi faktörlerin oldukça etkili olduğu belirtilmektedir. Ebe/hemşireler doğum sonrası ilk günlerde gözlem yoluyla ailelerin özellikle annelerin bebeklerine karşı duyarlılıklarını ve onların algılamalarını değerlendirerek olumsuz bağlanma davranışı gösteren anneleri izleyerek ileride oluşabilecek çocuk istismarı ve ihmalinin en aza indirilmesine yardımcı olabilirler. ${ }^{[12-15]}$

Bu araştırma, normal vajinal doğum ile sezaryen doğumun anne bebek etkileşimi ve annenin yenidoğanı algılaması üzerine etkisini belirlemek amacı ile kesitsel olarak yapıldı.

\section{Gereç ve Yöntem}

\section{Evren ve Çalışma Örneklemi}

Araştırmanın evrenini Sivas Devlet Hastanesi'nde doğum yapan 4457 anne ve yenidoğan; örneklemini ise 01 Ekim-31 Aralık 2007 tarihleri arasında doğum yapan 230 anne ( 115 normal doğum, 115 sezaryen doğum) ve yenidoğan oluşturmuştur. Araştırmanın örneklemi oluşturulurken, araştırmaya katılmayı kabul eden, sistemik hastalık ve ruhsal bozukluk tanısı alma- mış olan, postpartum herhangi bir komplikasyonu olmayan, bebeği ile aynı ortamda bulunan, ilk bebek sahibi olan, Apgar puanı 7'nin üzerinde, 37. gestasyonel haftasını tamamlamış, miadında, doğum ağırlığı 2500 gr üzerinde, anomalisi veya herhangi bir sorunu olmayan bebeklerin ve annelerinin alınması uygun kriter olarak kabul edilmiştir.

\section{Araştırmanın Sınırlılığı}

Aile-bebek etkileşimi değerlendirme ölçeğinin 3. gün formu gözlem gerektirdiğinden ve vajinal yolla doğum yapan annelerin 1. gün taburcu olması ve annelerin tamamına 3. gün ulaşılamaması nedeni ile 3. gün gözlemleri yapılamamıştır. Sadece ilk temas ve ikinci gün etkileşim ölçeği uygulanıp değerlendirilebilmiştir.

\section{Veri Toplama Aracı}

Araştırmanın verileri, "Anne-yenidoğan Tanıtıcı Özelliklerine İlişkin” soru formu, "Anne-Bebek Etkileşimi Değerlendirme Ölçeği (ABEDÖ) (İlk gün temas ve 2.gün temas bölümleri)", Yenidoğanı Algılama Ölçeği (YDAÖ) I (İlk gün) ve II (1 ay sonra) kullanılarak dört aşamada, gözlem ve yüz yüze görüşme yöntemi ile toplanmıştır. Araştırmacının kendisi tarafından YDAÖ I doğumdan hemen sonra, sezaryenli anne ameliyat servisine alınınca ve YDAÖ II doğumdan bir ay sonra annelere evinde ziyaret edilerek yüz yüze görüşme yöntemi ile uygulandı. ABEDÖ araştırmacı tarafından, doğrudan gözlem türü içinde yer alan "Katılımlı Gözlem" yöntemi ile sezaryenle doğum (SD) yapan annelerin yenidoğan bebekleriyle olan ilk temasları anne ameliyat servisine alındıktan sonra, vajinal yolla (VY) doğum yapan annelerin ilk temasları doğum odalarına alındıktan sonra ve ikinci gün uygulandı.

Anne-yenidoğan Tanıtıcı Özelliklerine İlişkin" soru formu, anne-yenidoğan etkileşimine yönelik bilgileri içeren toplam 37 sorudan (11 açık uçlu soru, 26 seçenekli soru) oluşmaktadır. Sorular ilgili literatür bilgileri ve 3 uzman görüşü (Pediatri Hemşireliği, Kadın Doğum Hemşireliği ve Halk Sağlığı Hemşireliği) alınarak hazırlanmıştır. Soruların anlaşılırlığını test etmek için 20 anneye anketin ön uygulaması yapılmıştır. Bu anneler çalışmaya dahil edilmemiştir.

Anne-Bebek Etkileşimi Değerlendirme Ölçeği (Ek II): Stainton $^{[16]}$ tarafından geliştirilen "Aile-Bebek Etkileşimi Değerlendirme Ölçeği (Parent Infant Interaction Assesment Scale)" doğum sonrası erken dönemde anne ve bebek arasındaki etkileşimin belirlenmesinde kullanılmaktadır. Ölçeğin geçerlilik ve güvenilirlik çalışması ülkemizde Pek tarafından ${ }^{[16]}$ yapılmış olup Cronbach alfa değerleri anneler için ilk temas 0.89 ve 2 . gün 0.86 olarak bulunmuştur.

Bu ölçek ailenin doğum sonrası erken dönemde bebeklerine karşı yanıtlarını, tepkilerini ve yakınlıklarını belirlemeyi amaçlayan, olumludan olumsuza doğru üçlü likert tipi bir ölçektir. Her bir ölçekte anne ve baba için 5 davranış sınıflaması bulunmaktadır. Bunlar; a) Bebek için duyarlılık, b) Dokunma/tutma, c) Göz göze ve yüz yüze iletişim, d) Yeterli bakım vermek, e) 
Hislerin anlatılması olarak özetlenebilir. Ölçekte tam puanı elde edebilmek için; her beş davranış kategorisinden en iyi tanımı veren madde işaretlenir. Beş davranış kategorisindeki her madde "2,1,0" puan verilerek gruplandırılır. Gözlem sonunda her kategorinin her biri puanlanarak toplam puan elde edilir. Ölçek, aile ve bebeklerinin doğumdan sonra ilk temas, 2. gün ve 3. Günlerde davranışları gözlenerek uygulanır. Elde edilen puanlarla, ebe/hemşire aile-bebek etkileşimi ve bağlanma konusunda ailenin ebe/hemşire gereksinimlerini belirler. Ölçekten alınan 8-10 arasındaki puan var olan ebe/hemşire desteğini (anne ve yenidoğan arasında etkileşimin başlamış olduğu ebe/hemşireden en az düzeyde destek gereksinime ihtiyaç vardır), 5-7 arasındaki puan birbirine bağlanmaları için özel ebe/hemşire desteğini (anne ve yenidoğan arasında etkileşimin başlamasında ebe/hemşireye intiyaç vardır), 0-4 arasındaki puan birbirine bağlanmaları için yoğun ebe/hemşire desteğini (anne ve yenidoğan arasında etkileşimin olmamasından dolayı ebe/hemşire anne ve yenidoğan ile özel olarak ilgilenmeli, etkileşimin başlaması için anneye destek olmalı, sürekli yanlarında kalmalıdır) gerektirir. Ebe/Hemşirelerin, annelerin rollerine uyumu ya da uyumsuzluğu olarak görülebilen davranışlarını da değerlendirmelerine yardımcı olur.

Yenidoğanı Algılama Ölçeği (YAÖ) (Ek III): Ölçek, Braussard ve Hartner tarafından geliştirilmiştir. ${ }^{[2]}$ Ülkemizdeki geçerlilik ve güvenilirlik çalışması $\mathrm{BalCl}^{[2]}$ tarafından yapılarak kullanılmıştır. Ölçeğin Cronbach's Alpha Değeri 0.77 dir. Ölçeğin amaCl; annenin bebeğini algılama durumunu ölçerek, bebeği ile ilgili beklentilerini ve bebeği ile olan ilişkilerindeki var olan sorunları saptayarak, ileride emosyonel bozukluğu olabilecek riskli bebekleri tanımlamaktır.

Ölçek, doğumdan sonraki, ilk günlerde uygulanan Yenidoğanı Algılama Ölçeği-1 (YAÖ-1) ve doğumdan 1 ay sonra uygulanan Yenidoğanı Algılama Ölçeği-2 (YAÖ-2) olarak iki bölümden oluşmaktadır. Doğumdan sonraki ilk günlerde uygulanan YAÖ-1 formu, annenin, herhangi bir bebeğin ve kendi bebeğinin ne gibi davranışları olacağı konusundaki algılarını içerir. Doğumdan 1 ay sonra uygulanan YAÖ-2 formu ise; annenin bebeği ile geçirdiği ilk 1 aylık sürede yaşadığı deneyimleri ve bebeğinin gerçek davranışları konusundaki algılarını içermektedir. Toplam 24 maddeden oluşan ölçeğin her bir maddesi, 1 'den 5'e doğru derecelenen 5'li likert tipi ölçektir. Hiç yanıtına "1" puan, çok az, orta derecede, biraz fazla, çok fazla yanıtlarına sırasıyla 2, 3, 4, 5 puan verilir. Likert tipi ölçek üzerindeki düşük değerler olması istenilen davranışı gösterir. YAÖ-1 ve YAÖ-2'den alınan puanlar ile yönergede belirtildiği şekilde annenin bebeğini algılama puanı hesaplanır. Sonuç: "0" olduğunda anne herhangi bir bebekle kendi bebeğini aynı algılıyor yani ortalama algilıyor. "0" dan büyük olduğunda anne bebeğini olumlu algılıyor. "0" dan küçük olduğunda ise olumsuz algıllyor demektir.

\section{Araştırmanın Etik Boyutu}

Araştırmada kullanılacak ölçeklerin kullanım izinleri ölçekleri Türkçe'ye uyarlayan araştırmacılardan sözel olarak alınmıştır. Araştırmanın yapılacağı kurumda uygulama izni ilgili hastane başhekimliğinden alınmış ve çalışmaya katılma kriterlerine uyan annelerle görüşülerek bilgilendirilmiş olurları da alınmıştır. Bu çalışma tanımlayıcı olan, soru formu ve ölçek uygulaması yapılarak değerlendirilen ve invaziv girişim içermeyen bir çalışma olduğundan etik kurul alınmamıştır.

\section{Verilerin Değerlendirilmesi}

Araştırmadan elde edilen veriler bilgisayarda (SPSS paket programı) yüzdelik, ortalama, standart sapma, t testi, ki-kare testi, tek yönlü varyans analizi, ileri Bonferroni testi, iki yönlü varyans analizi kullanılarak değerlendirilmiştir. Yanılma düzeyi, $p<0.05$ olarak alınmıştır.

\section{Bulgular}

Annelerin tanıtıcı özelliklerine ilişkin bulgular Tablo 1'de yer almaktadır. VY doğum yapan annelerin \%36.5'inin $21-26$ yaş, sezaryen ile doğum yapan annelerin \%36.5'inin 27-32 yaş grubunda oldukları belirlenmiştir. VY doğum yapan annelerin \%47'si ilkokul mezunu iken, sezaryen ile doğum yapan annelerin \%39.1'i ortaokul mezunudur. Ayrıca VY doğum yapan annelerin \%92.2'sinin, SD yapan annelerin ise \%96.6'sının ev hanımı olduğu belirlenmiştir. VY doğum yapan annelerin \%94.8'inin, sezaryen ile doğum yapan annelerin \%99.1'inin ilk evliliği olduğu; VY doğum yapanların \%59.2'sinin, SD yapan annelerin ise \%44.3'ünün 1-5 yıldır evli oldukları saptanmıştır. VY ile doğum yapan annelerin \%76.5'inin doğumunu ebenin, \%22.6'sının doğumlarını doktorun yaptırdığı belirlenmiştir. Annelerin doğum şekilleri ile yaş grupları $\left(X^{2}=5.620\right.$, $p=0.132)$, eğitim durumu $\left(X^{2}=1.788, p=0.617\right)$, çalışma duru$\mathrm{mu}\left(X^{2}=1.000, p=0.500\right)$, evlilik sayıları $\left(X^{2}=0.119, p=0.060\right)$, evlilik süreleri $\left(X^{2}=5.471, p=0.140\right)$ karşılaştıııldığında grupların özelliklerinin birbirine benzediği ve aralarındaki farkın önemli olmadığı belirlenmiştir.

Araştırma kapsamına alınan annelerin \%93.9'unun bebeklerini emzirdiği, emzirmeyen 14 (\%6.1) annenin doğum sonrası ağrılara dayanamama, meme sorunları, emzirme konusunda yeterince bilgi almamış olma gibi nedenlerden dolayı emziremedikleri belirlenmiştir. VY doğum yapan annelerin \%41.7'si, SD yapan annelerin \%40.9'un aile-bebek arasındaki bağları güçlendirici yöntemlerden dokunma, emzirme, kucağa alma, sevecen konuşma yöntemlerinin kullanılması gerektiğini ifade ettiği belirlenmiştir.

VY doğum yapan annelerin \%74.8'ine ( $\mathrm{n}=86)$ epizyotomi uygulaması yapılarak doğum gerçekleştirilmiştir. Yine VY doğum yapan annelerin \%94.8'inin $(n=109)$ yenidoğan bebeklerini doğduktan hemen sonra, SD yapan annelerin \%37.4'ünün $(\mathrm{n}=43)$ yenidoğan bebeklerini anestezinin etkisi geçtikten 31 $60 \mathrm{dk}$ sonra, \%20'si (n=23) $61 \mathrm{dk}-2$ saat sonra gibi sürelerde ilk kez gördükleri belirlenmiştir. Geri kalan anneler (vajinal yolla $n=5$, sezeyan ile $n=37$ ) ise bebeklerini hemen gördüklerini ancak onları kucaklayamadıklarını ifade etmişlerdir. Annelerin bebeklerini ilk görme zamanları ile doğum şekilleri arasındaki fark önemli bulunmuştur $\left(X^{2}=165.232, p=0.000\right)$. 
Tablo 1. Annelerin tanıtıcı özelliklerine göre dağılımı

Annelerin tanıtıcı özellikleri
Vajinal yolla doğum yapan

$(n=115)$
Sezaryen ile doğum yapan $(n=I \mid 5)$

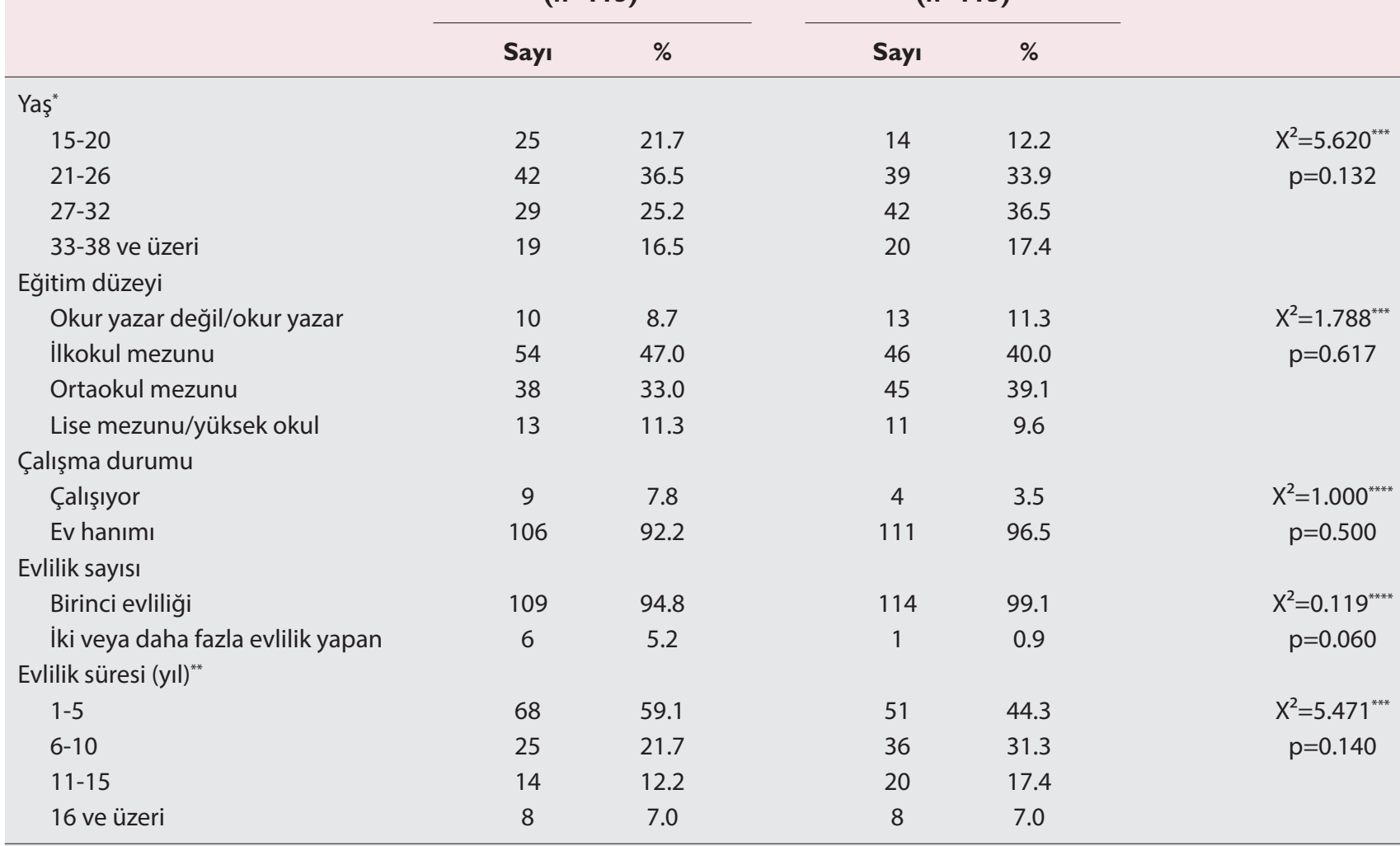

İstatistiksel değerlendirme

*Annelerin yaş ortalaması $24.9 \pm 6.48$, vajinal doğum yapan annelerde $24.3 \pm 6.01$, sezaryen ile doğum yapan annelerde $26.4 \pm 5.92$ 'dir.

**Annelerin evlilik süresi ortalaması $6.48 \pm 5.92$, vajinal doğum yapan annelerde $5.89 \pm 4.92$, sezaryen ile doğum yapan annelerde $7.08 \pm 5.82$ 'dir.

***istatistiksel değerlendirme "Yates Ki-kare Analizi" ile yapılmıştır.

****istatistiksel değerlendirme "Fisher Ki-kare Analizi” ile yapılmıştır.

Tablo 2'de ABEÖ'de ilk temas ve ikinci temas anne-yenidoğan etkileşim puanlarına göre ebe/hemşirelerin desteğine duydukları gereksinimin dağılımı görülmektedir. ABEÖ'de ilk temasa göre VY doğum yapan annelerin \%35.7'sinde var olan destek (anne ve yenidoğan arasında etkileşimin başlamış olduğu ebe/hemşireden en az düzeyde destek gereksinime ihtiyaç duyduğu), \%58.2'sinde özel destek (anne ve yenidoğan arasında etkileşimin başlamasında ebe/hemşireye ihtiyaç duyduğu), \%6.1'inde ise yoğun destek (anne ve yenidoğan arasında etkileşimin olmamasından dolayı ebe/hemşire anne ve yenidoğan ile özel olarak ilgilenmesine, etkileşimin başlaması için anneye destek olmasına, sürekli yanlarında kalmasına gereksinim) duyduğu belirlenmiştir. SD yapan annelerin ise \%26.1'i var olan desteğe, \%72.2'si özel desteğe, \%1.7'si ise yoğun desteğe ihtiyacı olduğu belirlenmiştir. Annelerin doğum şekilleri ile ilk temas anne-yenidoğan etkileşiminde ebe/hemşireye duydukları destek gereksinimleri arasındaki fark önemli bulunmuştur ( $\left.X^{2}=6.189, p=0.045\right)$ (Tablo2).

ABEÖ'de annelerin ikinci gün anne-yenidoğan etkileşim puanlarına göre ebe/hemşireden ihtiyaç duydukları destek gereksinimlerinin dağılımı Tablo 2'de verilmektedir. VY doğum yapan annelerin \%67.8'sinde var olan, \%31.3'sinde özel destek,
$\% 0.9^{\prime}$ da ise özel destek gereksinimleri olduğu belirlenmiştir. SD yapan annelerin ise \%45.2'i var olan desteğe, \%53.9'u özel desteğe gereksinimlerinin olduğu belirlenmiştir. Annelerin ikinci gün anne-yenidoğan etkileşiminde doğum şekilleri ile ebe/hemşirelerden ihtiyaç duydukları destek gereksinimleri arasındaki fark önemli bulunmuştur $\left(X^{2}=13.564, p=0.001\right)$.

Araştırmaya katılan annelerin doğum olayını tanımlama durumlarında, doğum olayını mutluluk verici olarak tanımlayan vajinal yolla doğum yapan annelerin ilk temas puan ortalamalarının (Ort=5.827士3.092), doğum olayını ağrılı (Ort=4.392 \pm 2.847 ) olarak tanımlayan annelerden daha yüksek olduğu belirlenmiştir. Yapılan iki yönlü varyans analizi sonucunda, VY ve SD yapan annelerin ilk temas toplam puan ortalamaları ile doğum olayını tanımlama durumları arasındaki etkileşim anlamlı bulunmuştur ( $F=1156.216, p=0.000)$. Bonferroni ileri analiz testi ile yapılan karşılaştırılmalar sonucunda; doğum olayını ağrılı ile mutluluk verici (ortalama fark=1.92, $\mathrm{p}<0.05$ ), korkunç ile mutluluk verici (ortalama fark=1.90, $\mathrm{p}<0.05$ ), korkunç ile ağrılı (ortalama fark=2.65, $\mathrm{p}<0.05$ ), ağrılı ile can yakıcı (ortalama fark=2.65, $\mathrm{p}<0.05$ ) olarak tanımlayanların ilk temas toplam puan ortalamaları arasındaki farkın anlamlı olduğu belirlenmiştir. 
Tablo 2. Illk temas anne-yenidoğan etkileşiminde annelerin ebe/hemşireden destek gereksinme durumlarının dağılımı

\begin{tabular}{|c|c|c|c|c|c|}
\hline \multirow[t]{2}{*}{$\begin{array}{l}\text { Ebe/hemşireden destek } \\
\text { gereksinme durumu }\end{array}$} & \multicolumn{2}{|c|}{$\begin{array}{l}\text { Vajinal yolla doğum yapan } \\
\qquad(n=1 \mid 5)\end{array}$} & \multicolumn{2}{|c|}{$\begin{array}{l}\text { Sezaryen ile doğum yapan } \\
\qquad(n=1 \mid 5)\end{array}$} & \multirow[t]{2}{*}{ İstatistiksel değerlendirme } \\
\hline & Sayı & $\%$ & Sayı & $\%$ & \\
\hline \multicolumn{6}{|l|}{ İlk gün } \\
\hline Var olan destek (8-10 puan) & 41 & 35.7 & 30 & 26.1 & $X^{2}=6.189^{*}$ \\
\hline Özel destek (5-7 puan) & 67 & 58.2 & 83 & 72.0 & $\mathrm{p}=0.045$ \\
\hline Yoğun destek (0-4 puan) & 7 & 6.1 & 2 & 1.7 & \\
\hline \multicolumn{6}{|l|}{ İkinci gün } \\
\hline Var olan destek (8-10 puan) & 78 & 67.8 & 52 & 45.2 & $X^{2}=13.564^{*}$ \\
\hline Özel destek (5-7 puan) & 36 & 31.3 & 62 & 53.9 & $p=0.001$ \\
\hline Yoğun destek (0-4 puan) & 1 & 0.9 & 1 & 0.9 & \\
\hline
\end{tabular}

*istatistiksel değerlendirme "Fisher Ki-kare Analizi” ile yapılmıştır.

VY ve SD yapan anneler doğum olayını\%56.5-65.2 ( $n=65$, $n=75)$ oranında ağrılı bir olay, \%27.8-19.1 ( $n=32, n=22)$ oranında mutluluk verici bir olay olarak tanımlarken; her iki grupta da annelerin \%15.7'si ( $n=18)$ doğum olayını "korkunç bir olay" olarak tanımlamışlardır. VY ve SD ile doğum yapan annelerin doğum olayını tanımlama durumları ile doğum şekilleri arasındaki farkın önemli olmadığı ( $p>0.05$ ), fakat anne-bebek etkileşimi ile doğum olayını tanımlama arasındaki farkın önemli olduğu belirlenmiştir $(p<0.05)$. Ayrıca Bonferroni ileri analiz testiyle yapılan karşılaştırmalar sonucunda, anne-bebek etkileşimi ilk temas ve ikinci gün temas puan ortalamaları arasındaki fark anlamlı bulunmuştur $(p<0.05)$. Bu veriler sonucunda doğum olayını mutluluk verici olarak tanımlayan annelerin, doğum olayını ağrılı olarak tanımlayan annelere göre anne-bebek etkileşim puanlarının daha yüksek olduğu ve etkileşimi daha erken dönemde başlatabildiği saptanmıştır.

İkinci gün toplam puan ortalamalarının annelerin doğum olayını tanımlama durumlarına göre dağılımında VY ve SD ile doğum yapan anneler arasında istatistiksel olarak anlamlı fark saptanmıştır. Araştırmaya katılan annelerin doğum olayını tanımlama durumlarında, doğum olayını mutluluk verici olarak gören VY doğum yapan annelerin ikinci gün puan ortalamalarının $(X=5.903 \pm 3.182)$ doğum olayını ağrılı $(X=4.482 \pm 2.729)$ olarak tanımlayan annelerden daha yüksek olduğu belirlenmiştir. Yapılan iki yönlü varyans analizinde, annelerin ikinci gün toplam puan ortalamalarında doğum şekilleri ile doğum olayını tanımlama durumları arasındaki etkileşim anlamlı bulunmuştur $(F=1406.517 p=0.000)$. Bonferroni ileri analiz testi ile yapılan karşılaştırılmalar sonucunda; doğum olayını ağrıı ile mutluluk verici (ortalama fark=1.610, $p<0.05$ ), korkunç ile mutluluk verici (ortalama fark $=2.19, p<0.05$ ), korkunç ile ağrıIı (ortalama fark=2.87, $p<0.05$ ), ağrılı ile can yakıc (ortalama fark=2.83, $\mathrm{p}<0.05$ ) olarak tanımlayanların ikinci gün toplam puan ortalamaları arasında anlamlı fark saptanmıştır.

Çalışmada ebe ya da hekimler tarafından doğumu kolaylaştırmak amacı ile vajinal yolla doğum yapan annelerin \%45.2'sine $(n=52)$ travay döneminde indüksiyonlu mayi uygulandığı, \%36.5'ine $(n=42)$ doğum sırasında annenin karnına kol ve dirsekle bastırma uygulandığı belirlenmiştir. Ayrıca annelerin \%74.8'ine $(n=86)$ epizyotomi uygulandığı saptanmıştır. Doğumu kolaylaştıran uygulamalarda vakum ve forseps uygulamasıyla karşılaşılmamıştır. Bu durumda olabilecek doğumlar sezaryen ile sonuçlanmıştır. Araştırmada vajinal doğumda epizyotomi yapılan annelerin \%74.8'inin $(n=86)$ vajinal doğumun en zor tarafının epizyotomi olduğunu ifade ettikleri, epizyotomi sonrası ağrı yaşadıkları ve bu ağrılara bağıı olarak, bebeklerini emzirirken zorlandıklarını ifade ettikleri belirlenmiştir. Bu sonuca göre epizyotomi uygulamasının emzirme üzerinde olumsuz bir etki oluşturduğu söylenebilir.

Çalışmada annelerin YAÖ'ne göre aldıkları puanların dağılımı değerlendiğinde; VY doğum yapan annelerin \%47.8'i $(n=55)$, SD yapan annelerin de \%58.3'ü $(n=67)$ bebeğini negatif algılamıştır. Annelerin bebeklerini negatif algılaması ile doğum şekilleri arasındaki fark değerlendirildiğinde farkın istatistiksel olarak önemli olmadığı belirlenmiştir $\left(X^{2}=0.235, p=0.118\right)$. VY doğum yapan annelerin $\% 52.2^{\prime}$ nin $(n=60)$, SD yapan annelerin ise \%41.7'nin ( $n=48)$ bebeğini pozitif algıladığı saptanmıştır. Annelerin bebeklerini pozitif algılaması ile doğum şekilleri arasındaki fark değerlendirildiğinde istatistiksel olarak anlamlı bir fark bulunmadığı belirlenmiştir $\left(X^{2}=1.410, p=0.235\right)$.

Annelerin yaş gruplarına göre bebeğini algılama durumlarının dağılımı değerlendirildiğinde; 21-26 yaş grubu VY doğum yapan annelerin \%19.1'i $(n=42)$, SD yapan annelerin de $\% 18.3$ 'ünün $(n=39)$ bebeklerini pozitif algıladıkları ve aralarındaki farkın ise istatistiksel olarak anlamlı olmadığı $\left(X^{2}=2.445\right.$, $\mathrm{p}=0.485)$ belirlenmiştir. Yine VY doğum yapan aynı yaş $(21-26$ yaş) grubu annelerin \%17.4'ü $(n=42)$ ile SD yapan $27-32$ yaş grubu annelerin \%19.1'inin $(n=42)$ bebeklerini negatif algıladıkları belirlenmiştir.

Annelerin bebeklerini ilk görme zamanlarına göre yenidoğanı algılama puan ortalamaları karşılaştıııldığında, ilk görme zamanlarına göre negatif algılama puanları arasında istatistiksel olarak anlamlı bir fark bulunmuştur ( $F=1339.335, p=0.000)$. Pozitif algılayan annelerin ilk görme zamanlarına göre istatistik- 
Tablo 3. Annelerin bebeklerini ilk görme zamanlarına göre yenidoğanı algılama puan ortalamalarının karşılaştırıması

\begin{tabular}{|c|c|c|c|c|}
\hline \multirow[t]{2}{*}{$\begin{array}{l}\text { Annelerin bebeklerini ilk görme } \\
\text { zamanları }\end{array}$} & \multirow{2}{*}{$\frac{\text { Pozitif algılama }}{\text { Ort. } \pm S S}$} & \multirow{2}{*}{$\frac{\text { Negatif algılama }}{\text { Ort. } \pm S S}$} & \multirow{2}{*}{ 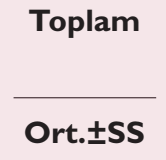 } & \multirow[t]{2}{*}{$\begin{array}{l}\text { İstatistiksel } \\
\text { değerlendirme }\end{array}$} \\
\hline & & & & \\
\hline \multicolumn{5}{|l|}{ Vajinal doğum yapanlar } \\
\hline Doğumdan hemen sonra $(n=109)$ & $10.2 \pm 0.1672$ & $6.3 \pm 0.1879$ & $8.4 \pm 0.2677$ & $F=1339.335$ \\
\hline Doğumdan 0-30 dakika sonra $(n=5)$ & $9.3 \pm 1.0154$ & $4.7 \pm 0.0175$ & $5.6 \pm 0.8367$ & $p=0.000$ \\
\hline 61 dakika-2 saat sonra & 0 & 0 & 0 & \\
\hline 2 saatten sonra & 0 & 0 & 0 & \\
\hline \multicolumn{5}{|l|}{ Sezaryen doğum yapanlar } \\
\hline Doğumdan hemen sonra $(n=12)$ & $11.2 \pm 1.8744$ & $6.4 \pm 0.1734$ & $10 \pm 1.8892$ & $F=1605.482$ \\
\hline Doğumdan 0-30 dakika sonra $(n=37)$ & $8.3 \pm 1.0673$ & $8.1 \pm 1.0026$ & $8.2 \pm 1.0637$ & $p=0.004$ \\
\hline
\end{tabular}

Ort.: Ortalama; SS: Standart sapma.

Tablo 4. vajinal ve sezaryen doğum yapan annelerin ABEDö toplam puanlarının, yenidoğan bebeklerini ilk görme zamanlarına göre dağılımı

\begin{tabular}{|c|c|c|c|c|c|c|c|}
\hline \multirow{2}{*}{$\begin{array}{l}\text { Annelerin bebeklerini ilk görme } \\
\text { zamanları }\end{array}$} & \multicolumn{2}{|c|}{ Pozitif algılama } & \multicolumn{2}{|c|}{ Negatif algılama } & \multicolumn{2}{|c|}{ Toplam } & \multirow{2}{*}{$\begin{array}{c}\text { İstatistiksel } \\
\text { değerlendirme }\end{array}$} \\
\hline & $\mathbf{n}$ & $\%$ & $\mathbf{n}$ & $\%$ & $\mathbf{n}$ & $\%$ & \\
\hline \multicolumn{8}{|l|}{ İlk temas ABEDÖ } \\
\hline Doğumdan hemen sonra & 109 & 94.8 & 12 & 10.4 & 121 & 52.6 & $F=942.270$ \\
\hline Doğumdan 0-30 dakika sonra & 5 & 4.3 & 37 & 32.2 & 42 & 18.3 & $p=0.000$ \\
\hline 31-60 dakika sonra & 1 & 0.9 & 43 & 37.4 & 44 & 19.1 & \\
\hline 61 dakika-2 saat sonra & 0 & 0 & 12 & 10.4 & 12 & 5.2 & \\
\hline 2 saatten sonra & 0 & 0 & 11 & 9.6 & 11 & 4.8 & \\
\hline \multicolumn{8}{|l|}{ İkinci gün ABEDÖ } \\
\hline Doğumdan hemen sonra & 109 & 94.8 & 12 & 10.4 & 121 & 52.6 & $F=1234.372$ \\
\hline Doğumdan 0-30 dakika sonra & 5 & 4.3 & 37 & 32.2 & 42 & 18.3 & $p=0.000$ \\
\hline $31-60$ dakika sonra & 1 & 0.9 & 43 & 37.4 & 44 & 19.1 & \\
\hline 61 dakika-2 saat sonra & 0 & 0 & 12 & 10.4 & 12 & 5.2 & \\
\hline 2 saatten sonra & 0 & 0 & 11 & 9.6 & 11 & 4.8 & \\
\hline
\end{tabular}

ABEDÖ: Anne-Bebek Etkileşimi Değerlendirme Ölçeği.

sel olarak anlamlı bir fark bulunmuştur ( $F=1605.482, \mathrm{p}=0.004)$ (Tablo 3). VY doğum ve SD yapan annelerde yenidoğanı algılama üzerinde oluşan bu farkın, SD yapan annelerin bebeklerini "31-60 dakika sonra" görmelerinden kaynaklandığı saptanmıştır $(p<0.05)$.

Vajinal ve sezaryen doğum yapan annelerin ABEDÖ toplam puan ortalamalarında yenidoğan bebeklerini görme zamanlarına göre dağılımı karşılaş̧ıııldığında (iki yönlü varyans analizi), ilk temas ABEDÖ puanları ile görme zamanları arasında istatistiksel olarak anlamlı bir fark bulunmuştur ( $F=942.270$, $\mathrm{p}=0.000$ ). Annelerin ikinci temasta ABEDÖ puanları ile bebek- lerini görme zamanları arasında istatistiksel olarak anlamlı bir fark bulunmuştur ( $F=1234.372, p=0.000$ ) (Tablo 4). İkinci temas puanlarında bu farkın, VY doğum yapan annelerin "doğumdan hemen sonra" bebeklerini görmelerinden kaynaklandığı görülmektedr $(p<0.05)$.

\section{Tartışma}

Çalışmada, doğum tipi değişkeninin anne- bebek etkileşimi ve annenin bebeğini algılaması üzerine etkisi incelendi. Literatürde bağlanmayı olumlu olarak etkileyen etmenlerden birinin 
doğumdan sonraki ilk saatlerde ve günlerde bebekle tensel temasın sağlanması olduğu belirtilmektedir. ${ }^{[6,17,18]}$ Soysal ve ark. [17] doğumdan sonra hemen ilk temasın sağlanmasıyla birlikte bağlanma ilişkisinde ilk ciddi adımların atılmış olduğunu belirtmektedir. Doğumu izleyen 30-60 dakikalık dönemde bebek uyanık ve alıc durumda iken anne-yenidoğan arasındaki çıplak deri teması, bebeğin çok yakın mesafede tutulması anne bebek etkileşiminin başlaması bakımından oldukça önemlidir. [13,18] Çalışmada vajinal doğum yapan annelerin \%94.8'nin bebeklerini doğumdan hemen sonra aldıkları ve doğum şekilleri arasında da bebeklerini ilk görme ve kucaklama zamanlarının anlamlı derecede farklı olduğu belirlenmiştir. Balcı ve Savaşer'in ${ }^{[1]}$ çalışmasında annenin doğumdan sonra bebeğini kucağa alma zamanı incelendiğinde; annelerin \%12'sinin ilk 1 saat içinde, \%76.1'inin 1-24 saat arasında ve \%12'sinin 24 saat sonra bebeklerini kucaklarına aldıkları saptanmıştır. Çalışmamızın sonucu daha düşük oranlara sahiptir. Bu araştırmada, vajinal yolla doğum yapan annelerin bebeklerini ilk görme zaman ortalamalarının 5.35 $\pm 2.86 \mathrm{dk}$ 'da olması anne bebek arasındaki ilişki ve bağlılığı olumlu yönde etkilemesi açısından önemlidir. ${ }^{[19]}$ Oysa sezaryen doğum yapan annelerin bebeklerini ilk görme zaman ortalamaları 30.38 20.65 dakikadır ve \%57.4'ü 31 dk ve üstü sürede bebeğini görmektedir. Annelerin bebeklerini ilk görme zamanları ile doğum şekilleri arasındaki fark önemli bulunmuştur $\left(X^{2}=165.232, p=0.000\right)$. Bu anne ve bebek arasındaki ilişki veya bağlılığın olumlu yönde gelişmesini geciktirdiği ve ayrılığa neden olduğu için bağlanmayı olumsuz etkileyebilir. ${ }^{[19,20]}$

Doğum sonrası duyarlı dönem olan ilk günlerde, annenin yanında olan ebe/hemşire, anne-yenidoğan arasındaki yeterli ve başarılı etkileşim sürecinin başlamasında, sürdürülmesinde önemli bir role sahiptir. Annenin bebeğini erken dönemde emzirmesi, bebeğine dokunması, kucaklaması, göz göze iletişim kurması, konuşması, sevmesi, okşaması, öpmesi annenin bebeği ile olan etkileşiminin etkili olduğunu gösterir. ${ }^{[13,20-23]}$ Bebeğin doğumdan hemen sonra anneye gösterilmeyip verilmemesi, anne ve bebeğin ayrı hasta odalarına alınması, emzirtmenin geciktirilmesi, emzirme süresinin kısa tutulması gibi istendik olmayan uygulama, tutum ve davranışlar yaygın olarak kullanılabilmektedir. Ebe/hemşirelerin anneleri olumsuz eleştirmeleri, çaba ve isteklerini kırmaları, kendi uygulamaları ve diğer nedenlerle emzirmeyi bölmeleri, annelere mama paketleri vermeleri, annelerin doğum sonrası emzirme deneyimini olumsuz yönde etkileyen uygulamalardandır.

Araştırma kapsamına alınan annelerin \%93.9'unun bebeklerini emzirdiği, emzirmeyen 14 (\%6.1) annenin doğum sonrası ağrılara dayanamaması, meme sorunları, emzirme konusunda yeterince bilgi almamış olması gibi nedenlerden dolayı emziremedikleri ve emzirme durumları ile doğum şekilleri arasındaki farkın ise anlamlı olmadığı ( $p>0.05$ ) belirlenmiştir. Sezaryen ile doğum yapıp emzirmeyen annelerin sezaryen yerinde ağrı ve bebeklerine karşı hissettikleri olumsuz duygular nedeni ile emzirmeye karşı isteksizlik duyduklarını belirttikleri gözlenmiştir. Çalışmamızı destekler nitelikte, Pek'in çalışması da, ${ }^{[16]}$ emzirmenin (\%90.0), sevecen ve yumuşak ses tonu ile konuşmanın
(\%83.3) ailenin bebek bağlarını güçlendirdiğini göstermiştir. Karaçam ve Eroğlu'da ${ }^{[24]}$ bu çalışmaya benzer biçimde doğum sonu ağrının anne -bebek ilişkisini etkilediğini belirtmiştir.

Annelerin doğumdan sonra bebeklerini ilk gördüklerinde neler hissettikleri sorulmuş ve vajinal yolla doğum yapan anneler ile (\%57.4), sezaryen doğum yapan annelerin (\%56.5) sevinçli ve mutlu oldukları, bebeklerini ilk gördüklerinde hissettikleri duygular ile doğum şekilleri arasındaki farkın anlamlı olmadığı saptanmıştır ( $p>0.05$ ). Doğum türü ile anne-bebek etkileşimini inceleyen çalışmalarda sezaryen ile doğumun bağlanma üzerine olumsuz etkilerinden söz edilmiştir. ${ }^{[9,17,25]}$ Sevindirici bir şekilde vajinal doğum yapan (\%41.7), sezaryen ile doğum yapan (\%40.9) annelerin aile-bebek arasındaki bağları güçlendirici yöntemlerden dokunma, emzirme, kucağa alma, sevecen konuşma yöntemlerinin kullanılması gerektiğini bildikleri saptanmıştır. Bu anne- bebek ilişkisini olumlu etkilemesi bakımından önemlidir. Ebe/Hemşire uygun koşullarda ilk beslenmeyi doğum masasında başlatabilir. Doğum sonu olabildiğince erken emzirme ile anne ve bebek birlikteliği de başlamış olur. Aynı odayı paylaşmalarını sağlanması ile anne kendi rolüne uyum gösterir ve bebeği ile etkileşimi artar. ${ }^{[8,26,27]}$

Araştırmaya katılan annelerin anne-bebek etkileşim ölçeğine göre puan dağılımları incelendiğinde, annelerin çoğunluğunun doğum sonrası dönemde anne-yenidoğan etkileşimi konusunda özel hemşire desteğine (ilk gün; VY doğumda \%58.2'si, SD yapanda \%72.2'si; ikinci gün, VY doğumda \%31.3'ü, SD yapanda \%53.9'unun) gereksinimlerinin olduğunu görülmektedir. Çalışmamızda özellikle sezaryen doğum yapan annelerin ilk temas ve ikinci gün temas anne-yenidoğan etkileşiminde önemli bir fark ile daha fazla desteğe ihtiyaç duydukları gözlenmektedir $(p<0.05)$. Pek'in ${ }^{[16]}$ çalışmasında ise daha az destek ihtiyaçları olduğu gözlenmektedir. Çalışmalar arasındaki farklılığın sebebi, her ne kadar annelik duygusu içgüdüsel ve her bebek için özel olsa da; Pek'in çalışmasının özel bir hastanede ve sosyoekonomik düzeyi iyi olan ailelerle yapılmış olması olarak düşünülebilir. Ebe/hemşire anne-yenidoğan ilişkisini değerlendirebilmek için; periyodik olarak anneyi gözlemeli, annenin bağlanma süreci ile ilgili detayları not almalıdır. Doğumdan hemen sonra yenidoğanı annenin göğsünde, anne ile yüz yüze ve göz göze gelecek şekilde tutmalı, emzirmeye yardımcı olmalı, uygun ortam bulunuyorsa babayı da bu birlikteliğe katmalı ve aile ile yenidoğan arasındaki etkileşimi başlatmalıdır. ${ }^{[7]}$ Cohn ve Tronick, ${ }^{[28]}$ annenin bebeğine ilettiği olumlu duygu ifadelerinin (gülümseme, "ce" türü oyunlar oynama ve hayvan sesleri çıkarma gibi) bebeklerde olumlu duygular uyandırdığını ve duruma uygun tepkiler verdiklerini belirlemişlerdir. İlk aylarda kurulan bu ilişki tarzı gelecekteki ilişki örüntülerinin ilk işareti niteliğinde görülmektedir ve önemlidir.

Sezaryen doğum yapan anneler VY doğum yapan annelere oranla bebeklerini daha az pozitif ve fazla negatif algılamışlardır. Ancak buna rağmen annelerin doğum şekli ile bebeklerini negatif ve pozitif algılamaları arasında anlamlı bir fark belirlenememiştir ( $p>0.05$ ).Yine çalışmamızda doğum tipi değişkeni farklı olan annelerin yaş gruplarına göre bebeklerini pozitif ve 
negatif algılamaları bakımından da anlamlı bir fark yaratmadığı belirlenmiştir. VY doğum yapan 21-26 yaş grubu annelerin \%17.4'ü ile SD yapan 27-32 yaş grubu annelerin \%19.1'inin bebeklerini benzer oranda negatif algıladıkları belirlenmiştir. Çalışmanın sonucuna göre negatif algılamayı, bu yaş gruplarında yaşadıkları ağrı deneyimi etkilemiş olabilir. Çalışmada VY doğumda doğduktan hemen sonra bebeğini görmenin pozitif algıyı artırdığı, farkın anlamlı olduğu; sezaryen doğumun negatif algıya neden olduğu ve hatta negatif algıyı artırdığı söylenebilir.

Araştırmaya katılan ve doğum olayını mutluluk verici olarak tanımlayan annelerin, doğum olayını ağrılı olarak tanımlayan annelere göre, anne-bebek etkileşim puanlarının daha yüksek olduğu ve etkileşimi daha erken dönemde başlatabildiği saptanmıştır. Anne -bebek etkileşimi zamanla öğrenilen bir süreçtir ve bu da annenin bebeğini algılamasını etkileyebilir. Bu etkileşimin sağlıklı başlayıp sürdürülmesinde, annenin rolüne uyumu, sezaryene bağlı sorunlarla baş edebilmesinde ebe/hemşire, çevreden aldığı destek ve eşler arasındaki uyum önemlidir. ${ }^{[8]}$ Güngör ve ark. ${ }^{[9]}$ yaptıkları çalışmada belirledikleri, doğum şeklinin annelik uyumuna etki ettiği ve sezaryen doğum yapanların güçlük çektikleri yönündedir. Bu güçlüklerin anne-bebek algısını negatif etkilemesi beklene doğal bir sonuçtur.

Mutlu ve ark.nın ${ }^{[15]}$ yaptığı çalışmada da doğum şeklinin anne-bebek bağlanması üzerinde etkili olmadığı belirlenmiştir. Hergüner ve ark.nın ${ }^{[25]}$ yaptığı çalışmada ise doğum şeklinin, maternal bağlanmayı etkilemediği belirlenmiştir. Tüm bunlara rağmen anne yaşının ve ailenin sosyo-ekonomik durumunun anne-yenidoğan ilişkisinin gelişmesinde etkili olduğu söylenmektedir. ${ }^{[1]}$ Manav ve Yıldırım ${ }^{[20]}$ annelerin bebeklerini ilk kucağa alma zamanlarını karşılaştırmışlar ve ilk $30 \mathrm{dk}$ term bebeklerini kucağa alan annelerin bebeklerini pozitif algıladıklarını belirlemişlerdir. Bizim çalışmamızda bebeklerini daha erken gören ve kucağına alan annelerin, ilk 30 dk'dan sonra bebeklerini gören annelerden daha pozitif algıladıkları saptanmıştır. Vajinal doğum yapanların ilk görme zamanı oranı doğumdan hemen sonra görenlere oranla bebeklerini daha pozitif algılamanın anlamlı derecede daha yüksek olduğu belirlenmiştir $(p=0.000)$. Bebeğini birinci reaktif dönemde gören (ilk $30 \mathrm{dk}$ ) annelerin bebeği en aktif dönemde görmeleri, bebeğin gözlerinin bu dönemde açık olması, güçlü emmesi ve çevresi ile ilgili olması nedeni ile algı pozitif olarak etkilenmiş olabilir. Çünkü bebek bu dönemde insan yüzüne gözlerini odaklayıp bakabilmektedir. ${ }^{[29,30]}$ Annelerin VY doğumdan hemen sonra bebeklerini görmesi (\%62.6) bu durumu daha pozitif etkilemiş olabilir. Ebe / hemşirelerin uygun koşullarda ilk beslemeyi doğum masasında başlatması, etkileşimi artıracağından, annenin bebeğini algılamasına katkı sağlayacaktır. ${ }^{[26,27,31]} \mathrm{Bu}$ çalışmada vajinal ve sezaryen doğum yapan annelerin bebeklerini ilk görme zamanları ile ilk ve ikinci temas anne-bebek etkileşimi değerlendirmeleri karşılaştırıldığında, yine her iki değerlendirme de vajinal doğum yapanların destek gereksiniminin sezaryenlere oranla anlamlı derecede daha az olduğu görülmektedir ( $p=0.000$ ). Diğer çalışmalarda da benzer biçim- de bebeğini ilk saatlerde görenlerle sonraki sürelerde görenler arasında bağlanmanın değiştiğini, ilk saatlerde görenlerde bağlanmanın daha yüksek olduğunu göstermiştir. ${ }^{[19,23,32-36]} \mathrm{Ma}$ nav ve Yıldırım'ın ${ }^{[20]}$ çalışmasında da ilk kucağa alma zamanı değerlendirildiğinde, özellikle doğumdan hemen sonra bebeğini kucaklayan annelerin bebeklerini pozitif algılaması daha anlamlı bulunmuştur. Ayrıca, annenin bebeğinin ilk kucağına aldığında kendine olan güven duygusunun arttığı ve bunun da annenin bebeğini pozitif algılamasını olumlu etkilediği söylenebilir. ${ }^{[1]}$

Bulgulardaki sınırlılıklar göz önüne alındığında özellikle çalışmanın kesitsel olması ve tek merkezde yapılması nedeni ile doğum sonrası tüm annelere genellenemeyebilir.

\section{Sonuç}

Çalışmanın sonucunda, özellikle sezaryen doğum yapan annelerin ilk temas ve ikinci gün temas anne-yenidoğan etkileşiminde önemli bir fark ile daha fazla desteğe ihtiyaç duydukları, doğumdan hemen sonra bebeğini görmenin pozitif algıyı artırdığı saptanmıştır. Sezaryen ile doğum yapan ve emzirmeyen annelerin sezaryen yerinde ağrı ve bebeklerine karşı hissettikleri olumsuz duygular nedeni ile emzirmeye karşı isteksizlik duydukları belirlenmiştir. Ebe/Hemşireler uygun koşullarda ilk beslenmeyi doğum masasında başlatarak, anne ve bebek birlikteliğini sağlayabilirler. Yine anne ile bebeğin aynı odayı paylaşmalarını sağlayarak annenin kendi rolüne uyumunu kolaylaştırarak, cesaretlendirerek bebeği ile etkileşimini artırabilir ve destekleyebilirler.

Çıkar çatışması: Bildirilmemiştir.

\section{Kaynaklar}

1. Balcı S, Savaşer S. Annelerin bebeklerini algılama durumu, VI. Ulusal Hemşirelik Kongre Kitabı. Ankara: Gata Hemşirelik Yüksek Okulu, 1998. s. 215-21.

2. Balcı S. İlk kez doğum yapan annelerin bebeklerini algılama durumları, İstanbul Üniversitesi: Sağlık Bilimleri Enstitüsü, Yüksek Lisans Tezi. İstanbul: 1997.

3. Bennett VR, Brown LK. Myles textbook for midwives, Editor. Mary E. 13. ed. Uprichard Dbe: Churchill Livingstone; 1999. p. 673-5, 700-3.

4. Efe ŞY, Taşkın L, Eroğlu K. Türkiyede postnatal depresyon ve etkileyen faktörler. J Turkish Germen Gynecol Assoc 2009;10:14-20.

5. Koçak DY, Büyükkayacı DN. Postpartum depresyon ve hemşirelik yaklaşımı. Psikiyatri/Nöroloji/Davranış Bilimleri Dergisi Sempozyum 2016;9:21-6.

6. Soysal SA, Bodur Ş, İşeri E, Şenol S. Bebeklik dönemindeki bağlanma sürecine genel bir bakış. Klinik Psikiyatri 2005;8:88-99.

7. Şeker S, Sevil Ü. Doğuma hazırlık sınıflarının annenin doğum sonu fonksiyonel durumuna ve bebeğini algılamasına etkisi. Ege Üniversitesi: Sağlık Bilimleri Enstitüsü, Doktora Tezi, İzmir: 2006.

8. Beydağ DK. Doğum sonu dönemde anneliğe uyum ve hemşirenin rolü. TSK Koruyucu Hekimlik Bülteni 2007;6:479-84. 
9. Güngör İ, GökyıldızŞ, Nahcıvan N. Sezaryen doğum yapan bir grup kadının doğuma ilişkin görüşleri ve doğum sonu erken dönemde yaşadıkları sorunlar. İstanbul Üniversitesi Florence Nıghtıngale Hemşirelik Yüksekokulu Hemşirelik Dergisi 2004;13:53-6.

10. Lewallen PL, Dick MJ, Flowers J, Powell W, Zickefoose KT, Wall YG, et al. Breastfeeding Support and Early Cessation. JOGNN 2006;35:166-72.

11. Öztop BD, Özcan ÖÖ, Uslu R, Erol N. Bebeklik ve erken çocukluk döneminin ruhsal-gelişimsel değerlendirilmesi: bebek ruh sağlığı ünitesi işleyişi. Çocuk ve Gençlik Ruh Sağlığı Dergisi 2007;14:16776.

12. Braungart-Rieker MJ, Garwood MM. Parental sensitivity, infant affect, and affect regulation: predictors of later attachment. Child Development 2001;72:252-70.

13. Güleşen A, Yıldız D. Erken postpartum dönemde anne bebek bağlanmasının kanıta dayalı uygulamalar ile incelenmesi. TAF Prev Med Bull 2013;12:177-82.

14. İşler A, Görak G. Prematüre bebeği olan annelerde olumlu annebebek ilişkisinin başlatılmasında hemşirelik yaklaşımının önemi. Çocuk Dergisi 2007;7:36-41.

15. Mutlu C, Yorbik Ö, Tanju İA, Çelikel F, Sezer RG. Doğum öncesi,doğum sırası ve doğum sonrası etkenlerin annenin bağlanması ile ilişkisi. Anadolu Psikiyatri Dergisi 2015;16:442-50.

16. Pek H. Sezaryen Doğumda Yaşamın İlk Üç Gününde Aile-Bebek Etkileşimi, I. Ulusal Perinatoloji Hemşireliği Sempozyumu. İstanbul:1996.

17. Soysal ŞA, Öktem F, Ergenekon E, Erdoğan E. Doğum türü değişkeninin bağlanma örüntüsü üzerindeki etkilerinin incelenmesi. Klinik Psikiyatri 2000;3:75-85.

18. Feldman R, Eidelman Al, Sirota L, Weller A. Comparison of skinto-skin (kangaroo) and traditional care: Parenting outcomes and preterm infant development. Pediatrics 2002;110:16-26.

19. Öztürk R, Saruhan A. Prematüre bebeği olan annelerin depresyon ve maternal bağlanma ilişkisi. Anadolu Psikiyatri Dergisi 2015;16:442-50.

20. Manav G, Yıldırım F. Term ve preterm bebek annelerinin bebeklerini algılama durumları. Cumhuriyet Tıp Dergisi 2010;32:149-57.

21. Kennell JH, Klaus $\mathbf{M H}$. Bonding: recent observations that alter perinatal care. Pediatrics in Review 1998;19:4-12.

22. Kinsey CB, Hupcey JE. State of the science of maternal-infant bonding: a principle-based concept analysis. Midwifery Dec
2013;29:1314-20.

23. Tallandini MA, Scalemebra C. Kangaraoo mother care and mother-premature infant dyadic interaction. Infant Maternal Health J 2006;27:251-75.

24. Karacam Z, Eroglu K. Effects of episiotomy on bonding and mothers' health. Journal of Advanced Nursing 2003;43:384-94.

25. Hergüner S, Çiçek E, Annagür A, Hergüner A, Örs R. Doğum Şeklinin doğum sonrası depresyon, algılana sosyal destek ve maternal bağlanma ile ilişkisi. Düşünen Adam The Journal of Psychiatry and Neurological Sciences 2014;27:15-20.

26. Görak G. Yenidoğan hemşireliğinde etik, (Ed) Türkan Dağoğlu, Gülay Görak, Temel neonatoloji ve hemşirelik ilkeleri. İstanbul: Nobel Tıp Kitabevi; 2002:31-40.

27. Hofer MA. The psychobiology of early attachment. Clinical Neuroscience Research 2005;20:1-10.

28. Cohn JF, Tronick EZ. Mother-infant face-to-face interaction: The sequence of dyadic states at 3,6, and 9 months. Developmental Psychology 1987;23:68-77.

29. Karabudak Sarıkaya S, Ergün S. Yenidoğan Hastalıkları ve Hemşirelik Bakımı, (Editörler). Conk Z, Başbakkal Z, Bal Yılmaz H, Bolışık B, Pediatri Hemşireliği. Ankara: Akademisyen Tıp Kitabevi Yayın Dağıtım ve Pazarlama Ltd. Şti.; 2013. s. 298-9.

30. Wong DL, Hockenbery MJ, Wilson D, Winkelstein ML, Kline NE. Wong's care of infants and children. 7th Edition. St. Louis: Mosby; 2003.

31. Bilgiç D, Güler H, Çetin A. Does early breastfeeding decrease the duration of the third-stage of labor and enhance the infantmother interaction? Artemis 2004;5:208-12.

32. Cho MY. Primiparas'perceptions of their delivery experience and their maternal-infant interaction: compared according to delivery method, Journal of The Korean Academy of Women's Health Nursing, 1995;1:5-22.

33. Klaus $M$, Kennell J. Parent to infant bonding: Setting the record straight. The Journal of Pediatrics 1983;102:575-6.

34. Kavlak $O$, Şirin A. Anne babaya ait bağlanma ve hemşirenin rolü. Ege Üniversitesi Hemşirelik Yüksekokulu Dergisi 2007;23:183-94.

35. Figuieredo B, Costa R, Pacheco A,Pais A. Mother to infant emotional involvement at birth. Maternal Child Health J 2009;13:539-49.

36. Goulet C, Bell L, Tribble DS, Paul D, Long A. A Concept analysis of parent,infant attachment. Journal of Advanced Nursing 1998;28:1071-81. 